\title{
KAJIAN HUBUNGAN TIMBAL BALIK ANTARA POLITIK DAN HUKUM
}

\author{
M. Agus Santoso \\ Dosen Fakultas Hukum Universitas Widya Gama Mahakam Samarinda
}

\begin{abstract}
ABSTRAK
Politik determinan atas hukum, dan hukum determinan atas politik, keduanya saling bersinggungan dan saling ketergantungan, tetapi dalam kenyataannya konfigurasi politik yang sangat dominan mempengaruhi karakter produk hukum. Sehingga kerap kali hukum kurang ditegakkan. Hal ini merupakan kajian politik hukum yang merupakan ilmu pengetahuan yang berdiri sendiri, tetapi tidak terlepas dari ilmu hukum dan ilmu politik
\end{abstract}

Kata kunci : Hubungan politik dan hukum

\section{PENDAHULUAN}

Tujuan Pembentukan Negara Republik Indonesia tertuang dalam pembukaan UUD 1945, pada alinea ke empat (4). Yang berbunyi :

1. Melindungi segenap bangsa Indonesia dan seluruh tumpah darah Indonesia

2. Memajukan kesejahteraan umum

3. Mencerdaskan kehidupan bangsa

4. Ikut melaksanakan ketertiban dunia yang berdasarkan kemerdekaan, perdamaian abadi, dan keadilan sosial.

Semua itu harus tercapai demi kesejahteraan dan kemakmuran masyarakat, dengan menjalankan keadilan yang merata bagi seluruh bangsa Indonesia, menuju masyarakat adil dan makmur, karena idaman masyrakat adil dan makmur dalam kehidupan bangsa Indonesia merupakan masalah pokok sepanjang sejarah ${ }^{1)}$, dan tekat itu telah dituangkan secara konstitusional di dalam Pembukaan UUD 1945 pada alinea ke empat, maka harus dijalankan secara konsekuen.

Adil dan makmur adalah dua pasangan yang tidak terlepaskan dalam falsafah hidup masyarakat dan merupakan tujuan hidupnya. Adil merupakan tekanan utama dan selalu disebutkan di depan kata makmur, adalah suatu penegasan dari prioritas yang perlu didahulukan ${ }^{2)}$ tentunya bangsa Indonesia mengidamkan suatu masyarakat yang adil dan makmur secara merata yang dicapai dengan cara yang wajar dan berperikemanusiaan, sehingga tercapai keselarasan, keserasian dan ketentraman di seluruh negeri ini.

1) Sunarjo Walujo, Prospek Adil-Makmur, Sasaran GNP Perkapita 5000 dollar, Pusat Pengembangan Agribisnis, 1979. hal.19. dimuat juga dalam C.F.G. Sunaryati Hartono, Politik Hukum Menuju Suatu Sistem Hukum Nasional, Alumni Bandung 1991. hal :2

2) Ibid 
Tujuan negara seperti terurai di atas dapat terwujud, salah satunya dengan menciptakan perangkat hukum yang kuat, di samping Indonesia merupakan negara yang berdasar atas hukum, sehingga diharapkan hukum yang dapat menjamin rasa keadilan oleh seluruh komponen masyarakat, karena hukum adalah sebuah entitas yang sangat kompleks, meliputi kenyataan kemasyarakatan yang majemuk, mempunyai banyak aspek, dan fase. ${ }^{3)}$ Jika diibaratkan benda, bagaikan sebuah permata yang tiap irisan sudutnya akan memberikan kesan berbeda bagi setiap orang yang melihat atau memandangnya.

Masalah kompleksitasnya hukum yang sejak jaman Yunani kuno, hukum senantiasa menarik perhatian dan menjadi wacana yang tidak henti-hentinya diperdebatkan oleh para cendikiawan. Sehingga menyebabkan hukum itu dapat dipelajari dari berbagai sudut pandang, yang kemudian melahirkan disiplin hukum: yaitu filsafat hukum (phylosophy of law) dan ilmu hukum (science of law), kemudian berkembang lebih banyak seperti teori hukum (theory of law), sejarah hukum (history of law), sosiologi hukum (Sociology of law), antropology hukum (antropology of law); perbandingan hukum (comparative of law), logika hukum (logic of law), psikologi hukum (psychology of law), dan yang kini sedang tumbuh politik hukum (politic of law). ${ }^{4)}$

Masing-masing disiplin hukum itu merupakan disiplin ilmu yang mandiri, namun demikian kesemuanya tidak bisa bekerja secara sendiri-sendiri, karena sebenarnya semuanya saling berhubungan antara satu dan lainnya, artinya satu disiplin hukum tidak memiliki makna apa-apa tanpa melibatkan disiplin hukum yang lain, kesemuanya itu merupakan ilmu bantu yang dapat dimanfaatkan sebagai pendekatan, yang secara sinergis bekerja secara sistematis dan komprehensip untuk dapat menggali dan menjelaskan apa sesungguhnya hukum itu dan bagaimana proses pembentukan hukum itu, namun tanpa bermaksud mangabaikan disiplin hukum yang lain, tulisan ini hanya akan memfokuskan diri untuk membahas satu disiplin hukum, yaitu politik hukum.

Politik dan hukum, masing-masing merupakan ilmu pengetahuan yang berdiri sendiri, dan ilmu politik juga terdiri dari beberapa mata kuliah yang berdiri sendiri yang merupakan sub bagian ilmu pengetahuan ilmu politik, seperti Pengantar Ilmu Politik, Sistem Politik, kekuatan-kekuatan politik, komunikasi politik, dan sebagainya; begitu juga ilmu hukum, yang terdiri dari beberapa mata kuliah yang berdiri sendiri dan merupakan sub bagian dari ilmu hukum seperti : pengantar ilmu hukum, hukum perdata, hukum pidana, hukum tata negara dan sebagainya, politik hukum bukan merupakan bagian dari ilmu politik atau ilmu hukum, tetapi politik hukum merupakan ilmu pengetahuan yang berdiri sendiri yang sudah memenuhi syarat seperti kita anut selama ini khususnya untuk ilmuilmu sosial bahwa ilmu adalah pengetahuan yang tersusun, sedangkan pengetahuan adalah pengamatan yang disusun secara sistematis. ${ }^{5)}$

\footnotetext{
3) Bernard Arief, Sidarta, Refleksi tentang Struktur Ilmu Hukum : Sebuah Penelitian tentang Fondasi Kefilsafatan dan Sifat Keilmuan. Ilmu Hukum Sebagai Landasan Pengembangan Ilmu Hukum Nasional Indonesia, Mondar Maju, Bandung 1999. hal : 116

4) Satjipto Rahadjo, Ilmu Hukum, Alumni Bandung 1991, hal : 325-359

5) Bintan Regen Saragih, Politik Hukum, CV.Utomo Bandung 2006, hal:3
} 
Secara analogi politik hukum telah dapat disebut sebagai ilmu pengetahuan sendiri karena sudah memenuhi syarat dan mempunyai ciri-ciri sebagai berikut :

1. Jelas obyek ontologinya, karena jelas obyek yang ditelaahnya membuahkan pengatahuan, yaitu tentang hukum sebagai suatu kebijakan dari lembaga atau pejabat yang berwenang

2. Jelas landasan epistemology, karena diperoleh melalui pengalaman dan akal sehat, yaitu pengalaman yang ditempuh dalam proses kebijakan untuk menetapkan hukum baik pada masa lalu maupun masa sekarang ini dan dikaji secara ilmiah

3. Jelas landasan aksiologisnya, karena dengan mempelajari politik hukum, kita akan mengetahui apakah hukum yang ditetapkan itu bermanfaat buat masyarakat atau tidak, atau apakah hukum yang ditetapkan itu menjauhkannya dari realitas sosial atau tidak. ${ }^{6)}$

Politik hukum sebagai ilmu yang berdiri sendiri, pasti selalu menyangkut bidang ilmu politik dan bidang ilmu hukum, oleh karenanya selalu ada benang merah antara politik dan hukum yang selalu bersinggungan dan saling berhubungan, dan untuk memperjelas hubungan timbal balik antara politik dan hukum perlu dikaji lebih dalam, guna mendapatkan diskripsi yang jelas hubungan antara politik dan hukum tersebut, maka dalam kesempatan ini penulis merasa berkewajiban untuk menggali lebih dalam hubungan antara politik dan hukum, dengan memaparkan dalam sebuah tulisan dengan judul Kajian Hubungan Timbal Balik Antara Politik dan Hukum, dalam konteks ilmu pengetahuan politik hukum.

\section{PERMASALAHAN}

Masalah merupakan hal yang utama untuk dikemukakan sebelum seseorang peneliti merencanakan penelitiannya lebih lanjut. ${ }^{7)}$ Masalah itu dapat diperoleh dari kehidupan sehari-hari karena menjumpai hal-hal yang aneh atau didorong oleh keinginan meningkatkan hasil kerja apa saja. ${ }^{8)}$ Dan masalah itu dalam kehidupan sehari-hari lazim juga disebut dengan persoalan, ialah suatu yang terjadi tidak sesuai dengan keinginan dan keraguan. ${ }^{9)}$

Untuk memudahkan pembahasan dalam tulisan ini perlu dirumuskan sebuah masalah yang sesuai dengan topik dimaksud, yaitu Bagaimana hubungan timbal balik antara politik dan hukum?

Hal ini penting agar pembahasannya terfokus pada permasalahan dimaksud, di samping juga untuk membatasi agar tidak terlalu melebar terlalu jauh.

6) Jujun S Suriasumantri, Filsafat Ilmu, Sebuah Pengantar Populer. Pustaka Sinar Harapan Jakarta 1995. hal : 293

7) P.Joko Subagyo, Metode Penelitian Dalam Teori dan Praktek, Rineka Cipta, Jakarta 1991. hal : 13

${ }^{8)}$ Mordalis, Metode Penelitian Suatu Pendekatan Proposal, Bumi Aksara, Jakarta 2003. hal :34

9) Suharsini Arikunto, Prosedur Penelitian Suatu Pendekatan Praktek, Rineka Cipta, Jakarta 1992. hal : 22 


\section{HUBUNGAN ANTARA POLITIK DAN HUKUM}

Untuk mengetahui hubungan antara politik dan hukum, tentu harus memahami satu persatu apa itu politik dan apa itu hukum, menurut Aristoteles politik merupakan hakekat keberadaan manusia dalam kehidupan bermasyarakat ; jika dua orang atau lebih berinteraksi satu sama lain (dalam menjalani kehidupan di dunia), maka mereka tidak lepas dari keterlibatan dalam hubungan yang bersifat politik. ${ }^{10)}$ Maka jika ada manusia ingin meninjau status dan kedudukannya di dalam suatu masyarakat tertentu dalam segala aspek kehidupan yang berkelompok, semua itu pada hakekatnya melibatkan manusia-manusia ke dalam hal ikhwal politik, atau sekurang-kurangnya bersifat politik.

Politik merupakan bagian kegiatan yang dilakukan oleh manusia di dalam masyarakat, oleh karena itu politik pada hakekatnya adalah bagian daripada umat manusia. ${ }^{11)}$ Tidak dapat dipisahkan dari keterpaduannya dengan berbagai aspek kehidupan, bukan hanya kehidupan menyangkut salah satu aspek dalam kehidupan umat manusia, baik secara sadar maupun tidak sadar, tiap manusia adalah melakukan hal-hal yang bersifat politik serta berada dalam lingkungan yang disebut sistem politik, bahkan pada masa lampau ketika bentuk negara belum dikenal, di dalam lingkungan masyarakat adalah merupakan sistem politik, sehingga jelas bahwa jika berbicara tentang politik, sudah dapat dipastikan juga berbicara tentang manusia di dalam masyarakat.

Kemudian hukum adalah kumpulan dari berbagai aturan-aturan hidup (tertulis atau tidak tertulis), yang menentukan apakah yang patut dan tidak patut dilakukan oleh seseorang dalam pergaulan hidupnya, suatu hal khusus yang terdapat pada peraturan-peraturan hidup itu, yakni bahwa untuk pentaatannya ketentuan itu dapat dipaksakan berlakunya. ${ }^{12)}$ Selanjutnya yang dimaksud tujuan hukum yang sebenar-benarnya, bahwa hukum menghendaki kerukunan dan kedamaian dalam pergaulan hidup bersama, hukum itu mengisi kehidupan yang jujur dan damai dalam seluruh lapisan masyarakat. ${ }^{13)}$

Jika berbicara tentang hukum, sudah pasti berbicara tentang manusia di dalam masyarakat, dan tidak bisa hanya manusia sebagai individu sendiri, manusia tidak bisa hidup tanpa ada manusia yang lainnya, karena manusia itu sebagai makhluk pada dasarnya selalu ingin bergaul dan berkumpul dengan sesama manusia lainnya, jadi makhluk yang suka bermasyarakat. Dan oleh karena sifatnya yang suka bergaul satu sama lain, maka manusia itu disebut makhluk sosial. ${ }^{14)}$ Hukum bekerja dalam kehidupan sosial, semakin majemuk masyarakat semakin kompleks pula hukum, dan bekerjanya pun semakin luas cakrawalanya. ${ }^{15)}$

\footnotetext{
10) T.May Rudy, Pengantar Ilmu Politik, Wawasan Pemikiran dan Kegunaannya, Replika Aditama 2003. hal : 1

11) Ibid. hal : 2

${ }^{12)}$ Soedjono Dirdjosisworo, Pengantar Ilmu Hukum, Rajawali Pers, Jakarta 1991. hal : 10

13) Ibid. hal : 17

14) C.S.T.Kansil, Pengantar Ilmu Hukum dan Tata Hukum Indonesia, PN.Balai Pustaka, Jakarta 1984. hal : 29

${ }^{15)}$ Soedjono Disdjosisworo. Op cit. hal : 7
} 
Politik dan hukum sama-sama merupakan kegiatan manusia di dalam masyarakat, sehingga antara politik dan hukum itu ada benang merah yang menghubungkan antara keduanya, jika dapat diibaratkan politik dan hukum itu sebagai dua sisi dari satu mata uang logam, maksudnya bahwa hubungan antara politik dan hukum itu sangatlah erat, sehingga susah juga digali lebih dulu mana antara politik dan hukum itu dilahirkan atau ada, dan jika diibaratkan pula seperti telur dan ayam, telur berasal dari ayam, sedangkan ayam itu juga bisa ada karena telur, keduanya saling mempengaruhi begitu juga politik dan hukum.

Di dalam studi mengenai politik dan hukum sebenarnya terdapat tiga asumsi yang mendasari, yaitu :

1. Hukum determinan atas politik, dalam arti bahwa hukum harus menjadi arah dan pengendali semua kegiatan politik. Asumsi ini dipakai sebagai landasan das sollen (keinginan, keharusan, dan cita-cita)

2. Poitik determinan atas hukum, dalam arti bahwa dalam kenyataannya baik produk normatif maupun implementasi penegakannya, hukum itu sangat dipengaruhi dan menjadi dependent variable atas politik. Asumsi ini dipakai sebagai landasan das sain (kenyataan, realitas) dalam studi hukum empiris.

3. Politik dan hukum terjalin dalam hubungan yang interdependent atau saling tergantung yang dapat dipahami dari adagium yang sangat terkenal tentang ini, "Politik tanpa hukum menimbulkan kesewenang-wenangan atau anarkis, hukum tanpa politik akan menjadi lumpuh." 16)

Ada asumsi lain menyebutkan terhadap hubungan linier antara konfigurasi politik dan kekuasaan kehakiman, yaitu apabila dalam suatu negara diterapkan suatu konfigurasi politik yang demokratis, karakter kekuasaan kehakiman yang dihasilkan oleh konfigurasi politik semacam itu adalah karakter kekuasaan kehakiman yang independen atau otonom, begitu pula apabila yang diterapkan konfigurasi politik otoriter atau totaliter, yang dihasilkannya adalah karakter kekuasaan kehakiman yang tidak otonom atau tidak bebas. ${ }^{17)}$

Dari asumsi-asumsi tersebut dapat ditarik kesimpulan, yaitu terdapat keterkaitan yang erat antara politki dan hukum, walaupun obyeknya berbeda, yang satu menekankan pada aspek keterkaitan antara konfigurasi politik dan karakter produk hukum, sedangkan asumsi lainnya menekankan pada aspek keterkaitan antara konfigurasi politik dan karakter kekuasaan kehakiman, apakah ia bersifat otonom atau tidak otonom, dan keduanya berpendapat bahwa konfigurasi politik sangat mempangaruhi karakter produk hukum dan karakter kekuasaan kehakiman.

Dari uraian tersebut di atas semakin jelas, bahwa hubungan antara politik dan hukum bukan saja keterkaitan sangat erat, tetapi bahkan saling ketergantungan, karena hukum dalam arti undang-undang itu lahir karena proses politik, dan pelaksanaan hukum itu sendiri memerlukan politik yang dinamakan kekuasaan, dan di sisi lain proses politik itu juga memerlukan adanya aturan hukum yang jelas, begitu juga kekuasaan harus ada batasan-batasan aturan hukum

16) Moh. Mahfud MD, Pergulatan Politik dan Hukum Di Indonesia, Gama Media, Yogyakarta 1999. hal : XI-XII

17) Imam Syaukani dan A.Ahsin Thohari, Dasar-dasar Politik Hukum, Raja Grafindo Persada, Jakarta 2004. hal : 6-7 
yang mengaturnya, sehingga pelaksanaannya tidak sewenang-wenang, begitu seterusnya politik hukum yang berlaku di suatu negara.

Kedudukan hukum dalam suatu negara sebagian merupakan hasil perjuangan politik, hukum pada umumnya adalah sebagai hasil perjuangan dari kelompok-kelompok politik yang dominan dalam suatu negara, dan bahkan ada anggapan hukum itu tidak lain hanyalah perumusan kemauan politik dari pihak yang berkuasa, maka sebagai konsekuensinya, hukum tidak mungkin hanya dilihat sebagai sesuatu yang bersifat otonom dalam kehidupan masyarakat, akan tetapi selalu mempunyai keterkaitan dengan berbagai variabel sosial kemasyarakatan yang satu diantaranya adalah politik. Maka kelompok-kelompok politik dan proses politik itu sangat menentukan karakter produk hukum dalam suatu negara. Begitulah hubungan yang erat antara politik dan hukum itu di suatu negara.

\section{HASIL DAN PEMBAHASAN}

Hubungan antara politik dan hukum dapat diibaratkan sebagai dua sisi dari satu mata uang logam, artinya hubungan di antara keduanya sangatlah erat, dan saling bersinggungan di dalam membicarakan penyelenggaraan negara dari tingkat pusat sampai tingkat daerah politik dan hukum selalu mendapat tempat yang utama, hukum selalu menjadi sarana dari politik untuk mempengaruhi, membangun dan mengembangkan bidang-bidang yang lain, dalam hal ini berlakulah tesis bahwa hukum adalah putusan politik (law is a political decision). ${ }^{18)}$

Asumsi dasar yang berkembang adalah bahwa hukum merupakan produk politik sehingga karakter setiap prduk hukum akan sangat ditentukan atau diwarnai oleh konfigurasi politik yang melahirkannya. Dan berdasarkan kenyataan bahwa setiap produk hukum merupakan produk keputusan politik, sehingga hukum dapat dilihat sebagai kristalisasi dari pemikiran politik yang saling berinteraksi di kalangan politisi, walaupun dari sudut pandang das sollen bahwa politik harus tunduk pada ketentuan hukum yang ada, sehingga hukumlah yang seharusnya menjadi panglimanya. Tetapi dalam kenyataannya bahwa hukum ditentukan oleh konfigurasi politik yang melatar belakanginya.

Seringkali hukum itu tidak ditegakkan sebagaimana mestinya, karena adanya intervensi kekuatan politik, pada sisi lain juga dapat dilihat bahwa fungsi hukum cenderung merosot, hal ini yang menjadi keprihatinan, dan bahkan seorang pakar mengandaikan situasi tersebut seperti gambaran hubungan antara rel dan kereta api, jika rel diibaratkan hukum dan kereta api sebagai politik, akan terlihat bahwa kereta api itu telah berjalan di luar relnya. ${ }^{19)}$

Kekuatan konfigurasi politik dapat mempengaruhi produk hukum tertentu itu disebabkan karena konfigurasi politik merupakan variabel bebas atau variabel berpengaruh, sedangkan karakter produk hukum merupakan variabel terpengaruh, hal ini disebabkan karena konfigurasi politik itu merupakan kegiatan manusia di

\footnotetext{
18) Bintan Regen Saragih, 2006, Op.Cit. hal : 5

19) Moh. Mahfud MD,1999 Op.Cit. hal : 3
} 
dalam suatu kelompok tertentu, sampai pada suatu negara, maka sifatnya aktip, sedangkan karakter produk hukum yang dimaksud adalah hukum dalam arti Undang-Undang yang merupakan produk atau hasil dari interaksi para elit politik, maka hukum dalam arti Undang-Undang itu sifatnya pasif karena bukan merupakan kegiatan manusia.

Variabel konfigurasi politik dibagi atas konfogurasi yang demokratis dan konfigurasi yang otoriter, sedangkan variabel karakter produk hukum dibagi atas produk hukum yang berkarakter responsif atau otonom dan produk hukum yang berkarakter ortodoks/konservatif atau menindas, maka dapat diambil hipotesis bahwa konfigurasi politik yang demokratis akan melahirkan produk hukum yang berkarakter responsif atau otonom, sedangkan konfigurasi politik yang otoriter akan melahirkan produk hukum yang berkarakter konservatif/ortodoks atau menindas.

Konfigurasi politik yang sangat dominan dan begitu kuat mempangaruhi karakter produk hukum itu disebabkan adanya kekuasaan politik merupakan kemampuan untuk mempengaruhi kebijaksanaan umum atau pemerintah. Proses mempengaruhi ini dapat ditelusuri dari gejala awalnya sampai pada akibat dari pengaruh yang dilakukan. Kekuasaan politik ini hanya merupakan salah satu derivat bentuk kekuasaan sosial yang paling penting. Hal itu disebabkan karena secara global kekuasaan politik tumbuh dan berkembang dalam organisasi negara yang menjadi acuan kehidupan sosial terutama dalam masyarakat modern dewasa ini.. ${ }^{20)}$

Jika karakter produk hukum sangat dipengaruhi oleh adanya konfigurasi politik yang ada, maka konfigurasi politik itu sangat dipengaruhi oleh kondisi masyarakat yang ada pada suatu negara, karena konfigurasi politik itu dilakukan oleh para elit politik dalam suatu kelompok penguasa, misalnya partai politik, dan elit politik itu sendiri ditentukan oleh partisipasi politik setiap manusia dalam suatu masa tertentu, baik itu melalui pemilihan umum (pemilu legislatif) maupun pemilihan presiden dan wakil presiden serta pemilihan kepala daerah dan wakil kepala daerah yang tentunya sangat tergantung dari kondisi dan peran serta masyarakat.

Apabila peran serta dalam menyalurkan aspirasi politiknya, masyarakat sudah berlaku dewasa, jujur dan adil serta melakukan penilaian secara demokrasi dan cermat berdasarkan logika, bukan karena hal-hal yang menguntungkan diri sendiri, maka pasti akan melahirkan elit politik yang bisa melakukan konfigurasi politik secara demokrasi, yang pada akhirnya akan melahirkan karakter produk hukum yang responsip, tetapi sebaliknya apabila masyarakat apatis, kurang demokrasi dan tidak berfikir cermat, apalagi hanya mencari kepentingan sendiri, pasti akan melahirkan elit politik yang melakukan konfigurasi politik tidak demokratis atau otoriter, maka karakter produk hukum yang dihasilkanpun bersifat konservatif/ortodoks.

Hubungan politik dan hukum tidak bisa terlepas dari kondisi masyarakat yang ada pada suatu negara, maka hubungan ini ibarat mata rantai yang selalu ada ${ }^{20)}$ Deden Faturohman dan Wawan Sobari, Pengantar Ilmu Politik, Universitas Muhamadiyah
Malang 2004. hal : 25 
hubungannya, bahkan seperti simbiosis mutualisme, yaitu saling ketergantungan, yaitu hukum akan tergantung dari kondisi politik, dan kondisi politik itu sangat tergantung dengan kondisi masyarakat, kemudian kondisi mayarakat itu sendiri juga ditentukan oleh keberadaan hukum yang ada, maka untuk menegakkan hukum itu harus juga memandang kondisi politik dan bahkan kondisi masyarakat yang ada, pendek kata harus memperhatikan kondisi secara holistik.

Mencermati hubungan antara politik dan hukum, kemudian timbul pertanyaan, apakah hal itu merupakan kajian ilmu politik atau ilmu hukum? Jawabannya adalah bukan merupakan kajian ilmu politik dan juga bukan kajian ilmu hukum, tetapi merupakan kajian politik hukum yang berdiri sendiri sebagai ilmu pengetahuan sosial, dalam hal ini politik hukum termasuk bidang ilmu politik, seperti pendapat Utrecht yang mengatakan : "Perbuatan mencita-citakan hukum, yaitu membayangkan hukum, adalah suatu perbuatan politik hukum (daad van recht politick), dan kami meragukan apakah hukum yang dicita-citakan itu menjadi obyek ilmu hukum, menurut pendapat kami hukum yang dicita-citakan itu adalah proyek ilmu politik." ${ }^{21)}$

Hal yang berbeda adalah pendapat Moh. Mahfud MD, dari hasil penelitiannya dan berdasarkan argumentasi bahwa politik hukum merupakan bagian dari ilmu hukum bukan ilmu politik. Ia menjelaskan, bila ilmu hukum diibaratkan sebagai pohon, filsafat merupakan akarnya, sedangkan politik merupakan batangnya yang kemudian melahirkan cabang-cabang berupa berbagai bidang hukum, seperti hukum perdata, hukum pidana, hukum tata negara, hukum administrasi negara dan sebagainya. ${ }^{22)}$

Dalam hal ini penulis cenderung sependapat dengan pendapat Mahfud, bahwa politik hukum merupakan begian dari ilmu hukum, karena obyek dari politik hukum adalah hukum itu sendiri sebagai suatu kebijakan atau keputusan, maka politik hukum sangat pokok bagi para ahli hukum, selain itu juga lembaga yang berwenang menetapkan bahwa politik hukum itu adalah juga menjadi bahan studi dari ilmu hukum, terutama hukum tata negara dan hukum administrasi negara.

\section{KESIMPULAN}

Bahwa hubungan antara politik dan hukum ibarat dua sisi dari satu mata uang logam, artinya bahwa hubungan keduanya sangatlah erat, saling berhubungan dan saling ketergantungan. Politik determinant atas hukum, artinya bahwa proses politik itu harus berpedoman pada peraturan hukum yang ada, tidak boleh menyimpang dari aturan hukum. Kemudian hukum determinant atas politik, artinya bahwa hukum itu sangat dipengaruhi oleh proses politik dan dalam kenyataannya hukum itu selalu dikalahkan dengan proses politik.

Hukum merupakan produk politik, sehingga karakter setiap produk hukum akan sangat ditentukan atau diwarnai oleh konfigurasi politik yang melahirkannya, dalam kenyataannya setiap produk hukum merupakan produk

${ }^{21)}$ Utrecht.E. Pengantar Dalam Hukum Indonesia, Pustaka Sinar Harapan, Jakarta 1983. hal : 45

${ }^{22)}$ Moh.Mahfud MD, Politik Hukum di Indonesia, Cit 1, LP3ES, Yogyakarta. 1998, dimuat juga dalam Imam Syaukani dan A.Ahsin Thohari, Op.Cit. hal : 8 
keputusan politik, sehingga hukum dapat dilihat sebagai kristalisasi dari pemikiran politik yang saling berinteraksi di kalangan politisi, walaupun dalam sudut pandang das sollen bahwa politik harus tunduk pada ketentuan hukum yang ada, sehingga hukumlah yang menjadi panglimanya, bukan politik.

Begitulah hubungan antara politik dan hukum yang merupakan hubungan timbal balik dan saling ketergantungan, maka kajian ini bukan saja kajian ilmu politik atau ilmu hukum saja, tetapi merupakan kajian politik hukum yang yang merupakan ilmu pengetahuan yang berdiri sendiri.

\section{DAFTAR PUSTAKA}

Arief Sidarta, Bernard, Refleksi tentang Struktur Ilmu Hukum : Sebuah Penelitian tentang Fondasi Kefilsafatan dan Sifat Keilmuan. Ilmu Hukum Sebagai Landasan Pengembangan Ilmu Hukum Nasional Indonesia, Mondar Maju, Bandung 1999.

Arikunto, Suharsini, Prosedur Penelitian Suatu Pendekatan Proposal, Rineka Cipta, Jakarta 1992.

Dirdjosisworo, Soedjono, Pengantar Ilmu Hukum, Rajawali Pers, Jakarta 1991.

Faturohman, Deden dan Sobari, Wawan. Pengantar Ilmu Politik, Universitas Muhamadiyah Malang 2004.

Hartono, C.F.G. Sunaryati, Politik Hukum Menuju Suatu Sistem Hukum Nasional, Alumni Bandung 1991.

Kansil, C.S.T. Pengantar Ilmu Hukum Dan Tata Hukum Indonesia, PN.Balai Pustaka, Jakarta 1984.

Mahfud MD, Moh. Politik Hukum di Indonesia, Cit 1, LP3ES, Yogyakarta. 1998. , Pergulatan Politik dan Hukum Di Indonesia, Gama Media, Yogyakarta 1999.

Mordalis, Metode Penelitian Suatu Pendekatan Proposal, Bumi Aksara, Jakarta 2003.

Rahadjo, Satjipto, Ilmu Hukum, Alumni Bandung 1991.

Regen Saragih, Bintan, Politik Hukum, CV.Utomo Bandung 2006.

Rudy, T.May, Pengantar Ilmu Politik, Wawasan Pemikiran dan Kegunaannya, Replika Aditama 2003. 
Syaukani, Imam, dan Thohari, A.Ahsin, Dasar-dasar Politik Hukum, Raja Grafindo Persada, Jakarta 2004.

Suriasumantri, Jujun S, Filsafat Ilmu, Sebuah Pengantar Populer. Pustaka Sinar Harapan Jakarta 1995.

Subagyo, P.Joko, Metode Penelitian Dalam Teori dan Praktek, Rineka Cipta, Jakarta 1991.

Utrecht.E. Pengantar Dalam Hukum Indonesia, Pustaka Sinar Harapan, Jakarta 1983.

Walujo, Sunarjo, Prospek Adil-Makmur, Sasaran GNP Perkapita 5000 dollar, Pusat Pengembangan Agribisnis, 1979. 